Bolm Inst. oceanogr., S Paulo, 29(1):1-8, 1980

\title{
SIPUNCULA FROM SOUTHERN BRAZIL
}

EDWARD B. CUTLER* \& NORMA J. CUTLER*

Utica College of Syracuse University

\section{Synops is}

A collection of 291 sipunculans from the continental shelf off southerm Brazil is described. Ten species are included, two new to science (Phascolion medusae and Aspidosiphon longirhyncus). The latter comprises $74 \%$ of the specimens collected. Four are recorded for the first time in the southwestern Atlantic Ocean (Golfingia eremita, G. pellucida, A. albus, and A. exhaustus). The remaining two (G. misakiana and $P$. hedraeum) have been recorded from Brazilian waters before. While most of the material represents a warm, shallow water community (the southem end of the South Brazilian Province), another group of species found south of $34^{\circ} \mathrm{S}$ in deeper, cooler water points to the possibility of a zoogeographical barrier on the continental slope in these latitudes.

\section{Introduction}

This report is based on 291 sipunculans collected in 1968 and 1972 by the R/V "Prof. W. Besnard" as part of the program "Grupo Executivo do Desenvo1vimento da Indústria da Pesca do Rio Grande do Sul (GEDIP)" from the outer Continental Shelf of Southern Brazil. Most of the 22 stations came from depths between 50 and $200 \mathrm{~m}$ (also one each at 36,338 , and $1080 \mathrm{~m}$ ) with temperatures between 15 and $20^{\circ} \mathrm{C}$ (except the two deep ones). Table I lists the ten species (two new to science) found herein. Three of these are new records for the South Atlantic and one new for the Southwestern

Atlantic Ocean.

Complete descriptions of known species are not given here. The reader is referred to Stephen \& Edmonds (1972) for more details and complete morphological descriptions.

Systematics and distribution Golfingia (Apionsoma) misakiana (Ikeda, Sta. $1646 ; 34^{\circ} 25^{\prime} \mathrm{S}, 51^{\circ} 49^{\prime} \mathrm{W} ; \begin{aligned} & 166 \mathrm{~m} ; \\ & 8 \text { specimens }\end{aligned}$

These pale, translucent worms have spindle-shaped trunks, 2-5 mm long. The long slender introverts, bilobed

* Biology Department, Utica College of Syracuse University, Utica, New York 13502. U.S.A. nephridia, and posterior papillae are present. This species is discussed at length most recently in Cutler (1979) and Cutler \& Cutler (1979b) .

Previous records are from California, Peru, Brazil, East Africa, Australia, Japan, and French Polynesia. Unpublished records show its appearance in the Gulf of Mexico.

Golfingia (Golfingia) species

Sta. 1647; $34^{\circ} 25^{\prime} \mathrm{S}, 51^{\circ} 29^{\prime} \mathrm{W} ; 1080 \mathrm{~m}$; 2 specimens

Unfortunately, the small size (2 mm trunks) of these sole representatives of this subgenus precludes theiridentification to the species level. They have four retractor muscles of equal size and the anus is in the middle of the trunk near the retractor origins. The two nephridia are at the anterior end of the trunk and the introvert is longer than the trunk. The trunk itself is transparent and has papillae around the posterior end.

This could be a juvenile form of several species and shall be left unnamed. They may be Golfingia margaritacea as this species has been reported from this general area $\left(36-37^{\circ} \mathrm{S} ; 130\right.$ and $740 \mathrm{~m}$; Cutler \& Cut1er, 1979a).

Golfingia (Nephasoma) eremita (Sars,

Sta. 1647 ; $34^{\circ} 25^{\prime} \mathrm{S}, 51^{\circ} 29^{\prime} \mathrm{W} ; 1080 \mathrm{~m}$; 8 specimens

These small worms (trunks 1-4 mm) are placed here with some reservation. They possess the appropriate arrangement of 
Table I - List of species in this report. The asterisk indicates that this is the first report of this species from the Southwest Atlantic Ocean. Golfingia subgenera as in Cutler (1979)

Family Golfingi idae

Golfingia (Apionsoma) misakiana

Golfingia (Golfingia) species

Golfingia (Nephasoma) eremita*

Golfingia (Nephasoma) pellucida*

Golfingia (Nephasoma) species

Phascolion hedraeum

Phascolion medusae sp. nov.
Fami ly Aspidosiphonidae

Aspidosiphon albus*

Aspidosiphon exhaustus *

Aspidosiphon longirhyncus sp. nov. retractor muscles in the mid-trunk region, the two short nephridia and small, dome-shaped papillae around the posterior end. A few were sexually mature females with large spherical ova in the coelom. The trunk wall is light brown and translucent. Cutler (1973) has a detailed description of this species.

This is a common species in the Arctic and on both sides of the North Atlantic in waters cooler than $10^{\circ} \mathrm{C}$. There is one record off California at $500 \mathrm{~m}$. This $1080 \mathrm{~m}$ station at $3.5^{\circ} \mathrm{C}$ fits the niche parameters of this species.

\section{Golfingia (Nephasoma) pellucida} (Keferstein, 1865)

Sta. $1646 ; 34^{\circ} 25^{\prime} \mathrm{S}, 51^{\circ} 49^{\prime} \mathrm{W} ; 166 \mathrm{~m}$, 14 specimens

These translucent, pale tan worms are small for this species (Cutler, 1973). The trunk length ranges from 1.5 to $4 \mathrm{~mm}$. The typical tentacles and small hooks (height around $24 \mu \mathrm{m}$ ) are present. The trunk papillae characteristic of this species are present but restricted to the posterior half in some individuals. This may be related to their small size, the complete complement not yet developed.

Previously this species has been reported from the Caribbean as far north as North Carolina and in the Indonesian, Australian, New Zealand area into subtropical habitats. The depth $(166 \mathrm{~m})$ and temperature $\left(14.4^{\circ} \mathrm{C}\right)$ of this station are near the lower end of their known tolerance.

Golfingia (Nephasoma) species Sta. $1646 ; 34^{\circ} 25^{\prime} \mathrm{s}, 51^{\circ} 49^{\prime} \mathrm{W} ; 166 \mathrm{~m}$;

17 specimens

These worms are a heterogeneous group of smal1 (1-4 mm trunks) animals lacking developed tentacles and bearing scattered hooks. The shape varies from elongate and thin to short and rotund. They may be in the Golfingia minuta complex but cannot be further identified.

Phascolion hedraeum Selenka, de Man \& Burlow, 1883

Sta. $1656 ; 33^{\circ} 12$ 's, $50^{\circ} 34^{\prime} \mathrm{W} ; 173 \mathrm{~m}$;

Sta. $1696 ; 29^{\circ} 39^{\prime} \mathrm{S}, 48^{\circ} 41^{\prime} \mathrm{W} ; 124 \mathrm{~m}$; 2 specimens

Sta. $1697 ; 29^{\circ} 30^{\prime} \mathrm{S}, 48^{\circ} 57^{\prime} \mathrm{W} ; 86^{\mathrm{m}} \mathrm{m}$; 2 specimens

These five worms have trunks $3-6 \mathrm{~mm}$ long and are pale, pink-tan. The introvert is about twice the trunk length and bears tal1, spike-like hooks near the tentacles. The holdfasts are domed or rounded and widely distributed on the trunk. Internally the gut is coiled and the single nephridium opens at the anterior end of the trunk. The two retractor muscles are of equal size and originate at the posterior end of the trunk.

There are two previous records from Brazilian shelf waters and one record from southern Japan. These previous records are from shallower water for the most part $\left(5-115 \mathrm{~m}, 23-25^{\circ} \mathrm{S}\right)$.

Phascolion medusae sp. nov. Sta. 465; $34^{\circ} 35^{\prime} \mathrm{s}, 51^{\circ} 56^{\prime} \mathrm{W}$; $338 \mathrm{~m}$; 3 specimens Sta. $1646 ; 34^{\circ} 25^{\prime} \mathrm{S}, 51^{\circ} 49^{\prime} \mathrm{W} ; 166 \mathrm{~m}$; 1 specimen

The specimen from Sta. 1646 is only $2 \mathrm{~mm}$ long while the others are 12,18 , and 20 $\mathrm{mm}$ long by about $4 \mathrm{~mm}$ wide. The introvert is equal to the trunk in length and bears about 60 filamentous tentacles (Fig. 1). Behind the tentacles is the swollen area with hooks in irregular 


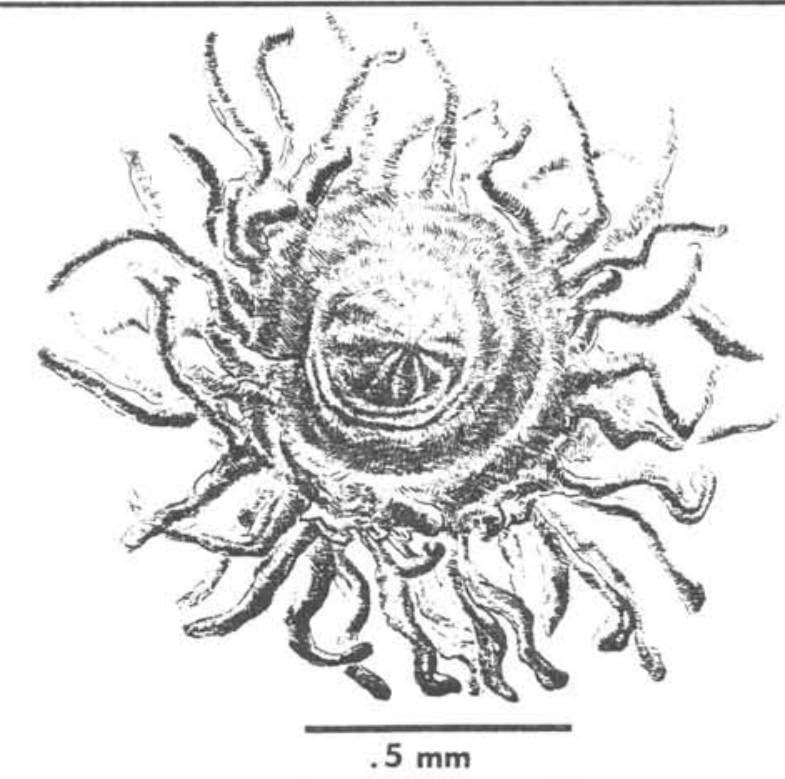

Fig. 1. Phascolion medusae tentacular crown.

rings measuring about $50 \mu \mathrm{m}$ tall with a base about $75 \mu \mathrm{m}$ wide. At the base of the introvert the skin is brown with minute flask-shaped papillae. The trunk is pale, greyish-tan and covered with papillae which lack a chitinized rim. They are up to $0.5 \mathrm{~mm}$ in diameter, mushroom-shaped or wart-1ike and bulbous, hollow, swollen structures, rather evenly distributed over all but the anterior 20 percent of the trunk (Fig. 2).

Internally the intestine has the typical Phascolion looped arrangement without any coil. The loops are attached posteriorly and midway in the trunk by fastening muscles. The rectum has a small caecum. The anus is anterior to the nephridiopore ( $3 \mathrm{mn}$ in the $18 \mathrm{~mm}$ worm). The single, cylindrical nephridium is attached to the body wall by mesentery for one-half its length. The two retractor muscles are very unequal in size. The ventral muscle is very thin and originates well in front of the posterior, dorsal one, just to the left of the ventral nerve cord. The origin of this thin muscle seems to be bifurcated but not always clearly so. The dorsal retractor muscle is much thicker and has a broad origin at the posterior of the trunk (Fig. 3). The esophagus parallels this muscle and carries with it the contractile vessel which has occasional bulbous outpouchings .

Among the Phascolion with two retractor muscles originating from

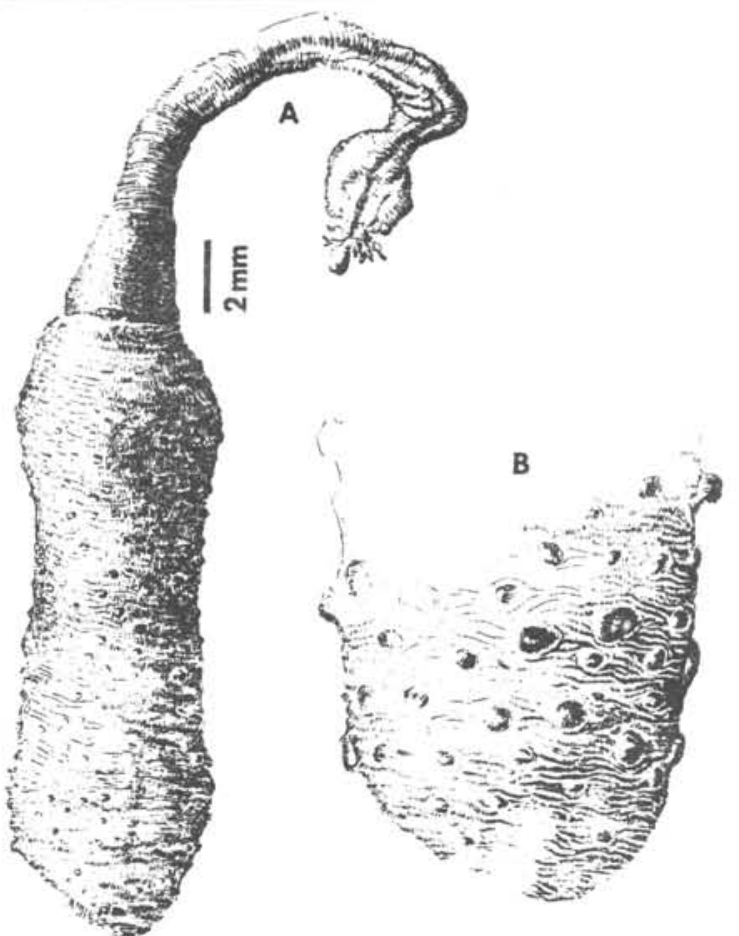

Fig. 2. Phascolion medusae -

A. external view;

$B$. enlargement of posterior end showing papillae.

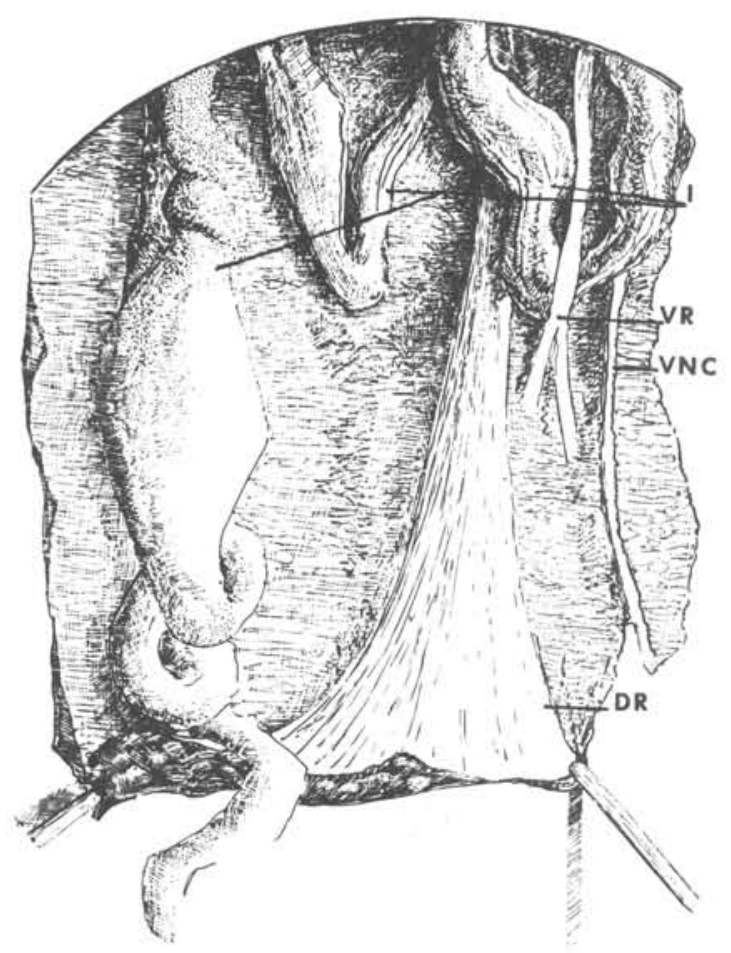

Fig. 3. Phascolion medusae internal view ( 1 - intestine, DR - dorsal retractor, VR - ventral retractor, VNC - ventral nerve cord). 
the posterior end, hooks, tentacles, and large non-chitinized papillae, there are three species. P. pallidum Koren \& Danielssen has less than 20 tentacles and only four rows of sharply bent, pointed hooks. P. Łucifugax Selenka \& de Man has a short introvert and the retractor muscles arise at the same level. The hooks are much more blunt and more stoutly built. P. tuberculosum Thee 1 is the most similar looking one, but has only 15 stumpy tentacles and the papillae often have chitinized borders of varying degrees of completion. Also the hooks differ in shape. A further distinction is that the two retractor muscles are of equal size in $P$. tuberculosum.

This species is named after the Greek goddess Medusa because of the large number of filiform tentacles. Holotype: Station 465 deposited in the American Museum of Natural History, New York; catalogue number AMNH 4023.

Paratype: Station 465 deposited at Instituto Oceanográfico, Universidade de São Paulo.

Aspidosiphon (Aspidosiphon) albus Murina,

Sta. 397; $29^{\circ} 45^{\prime} \mathrm{S}, 49^{\circ} 55^{\prime} \mathrm{W} ; 26 \mathrm{~m}$; 1967

Sta. $1676 ; 31^{\circ} 12^{\prime} \mathrm{S}, 50^{\circ} 35^{\prime} \mathrm{W} ; 59 \mathrm{~m}$;

1 specimen

1 specimen

The trunks are 5 and $7 \mathrm{~mm}$ long and both contained ova. The light brown, fine, granular anal shields with grooves and the poorly defined caudal shields characterize this species. The internal anatomy has no noteworthy features but on the larger worm the introvert seemed to be completely extended and, as well as having no hooks (normal) no tentacles were observed either. In the several recent reports of this species tentacles have yet to be seen.

Previous records are from shallow water off Cuba and the Southeastern United States (South of Cape Hatteras).

Aspidosiphon (Aspidosiphon) exhaustus Sluiter, 1912

Sta. $465 ; 34^{\circ} 35^{\prime} \mathrm{s}, 51^{\circ} 56^{\prime} \mathrm{W} ; 338 \mathrm{~m}$; 2 specimens

Sta. $1646 ; 34^{\circ} 25^{\prime} \mathrm{S}, 51^{\circ} 49^{\prime} \mathrm{W} ; 166 \mathrm{~m}$; 12 specimens

Sta. $1647 ; 34^{\circ} 25^{\prime} \mathrm{S}, 51^{\circ} 29^{\prime} \mathrm{W} ; 1080 \mathrm{~m}$; 1 specimen
Only one of these worms is over $5 \mathrm{~mm}$ long, most of them being around $2-3 \mathrm{~mm}$ (total range $1.5-10 \mathrm{~mm}$ ). The medium brown, grooved, distinct anal shield; well-defined, grooved caudal shield; and presence of only unidentate hooks is typical for this species. The posterior origin of the retractor muscles and the long nephridia also fit well. The pigmentation, especially in the anal shield, is noticeably age dependent. The younger, smaller worms (around $2 \mathrm{~mm}$ ) have much paler shields than the larger, older forms.

Previous records of this species are from 50-775 m off Northwest Africa, Arabian Sea, Mozambique/Madagascar, Australia, Indo-China, and the South Pacific. These are the first records from either side of the Americas of what might prove to be a circumtropical, sublittoral, bathyal species.

Aspidosiphon (Aspidosiphon) longirhyncus Sta. 293; $30^{\circ} 06^{\prime} \mathrm{S}, 48^{\circ} 56^{\prime} \mathrm{W} ; 133^{\mathrm{sp}} \mathrm{m}$; 31 specimens

Sta. $305 ; 31^{\circ} 41^{\prime} \mathrm{S}, 50^{\circ} 29^{\prime} \mathrm{W} ; 103 \mathrm{~m}$;

69 specimens

Sta. $313 ; 32^{\circ} 24^{\prime} \mathrm{s}, 51^{\circ} 22^{\prime} \mathrm{W} ; 57 \mathrm{~m}$;

2 specimens

Sta, $321 ; 33^{\circ} 31^{\prime} \mathrm{s}, 50^{\circ} 55^{\prime} \mathrm{W}$; $85 \mathrm{~m}$;

(34. 1 specimen

Sta. $330 ; 34^{\circ} 35^{\prime} \mathrm{s}, 52^{\circ} 00^{\prime} \mathrm{W} ; 148 \mathrm{~m}$;

Sta. $402 ; 30^{\circ} 33^{\prime} \mathrm{s}, 49^{\circ} 40^{\prime} \mathrm{W} ; 98 \mathrm{~m}$;

22 specimens

Sta. $413 ; 33^{\circ} 40^{\prime} \mathrm{s}, 51^{\circ} 46^{\prime} \mathrm{W} ; 78 \mathrm{~m}$;

Sta. $419 ; 34^{\circ} 00^{\prime} \mathrm{S}, 50^{\circ} 53^{\prime} \mathrm{W} ; 190 \mathrm{~m}$;

2 specimens

Sta. 432; $31^{\circ} 25^{\prime} \mathrm{s}, 50^{\circ} 17^{\prime} \mathrm{W} ; 112 \mathrm{~m}$;

Sta. 473 ; $33^{\circ} 47^{\prime} \mathrm{S}, 51^{\circ} 16^{\prime} \mathrm{W} ; 138 \mathrm{~m}$;

1 specimen

Sta. $1656 ; 33^{\circ} 17^{\prime} \mathrm{s}, 50^{\circ} 34^{\prime} \mathrm{W} ; 173 \mathrm{~m}$;

8 specimens

Sta. $1664 ; 32^{\circ} 46^{\prime} \mathrm{s}, 50^{\circ} 25^{\prime} \mathrm{W} ; 190 \mathrm{~m}$;

2 specimens

Sta. $1684 ; 30^{\circ} 46^{\prime} \mathrm{s}, 49^{\circ} 07^{\prime} \mathrm{W} ; 176 \mathrm{~m}$;

2 specimens

Sta. $1691 ; 30^{\circ} 10^{\prime} \mathrm{S}, 48^{\circ} 58^{\prime} \mathrm{W} ; 132 \mathrm{~m}$;

13 specimens

Sta. $1692 ; 30^{\circ} 20^{\prime} \mathrm{s}, 48^{\circ} 37^{\prime} \mathrm{W} ; 194 \mathrm{~m}$;

1 specimen

Sta. 1696; $29^{\circ} 39^{\prime} \mathrm{s}, 48^{\circ} 41$ 'W; $124 \mathrm{~m}$;

8 specimens

The 215 specimens from 16 stations have gray to pink trunks covered with very 
small skin bodies. Most are $10-15 \mathrm{~mm}$ but they range in length from $3-25 \mathrm{~mm}$ (4-10 times the diameter). Many are translucent but larger ones are opaque. While generally smooth looking, many worms have fine transverse grooves/ ridges/wrinkles in the skin, especially the larger and/or contracted individuals (Fig. 4a).

The shields are poorly developed, almost non-existent in some. The anal shield consists of scattered, weakly chitinized, flattened, wartlike papillae with very little pigmentation and no marked boundaries. The caudal end of the trunk does not exhibit any specialized shield but often has fine grooves radiating out from the center.

The introvert is long and thin, usually four to five times the trunk length. The length is often 100-200 times the diameter. The trunk/introvert angle is never the typical $90^{\circ}$ but usually around $50^{\circ}$ or $60^{\circ}$. No specimen has its introvert completely extended so no comments can be made about tentacle number or arrangement.

Unidentate hooks are present in i11defined rings and are 25-30 $\mu \mathrm{m}$ tall. They are almost transparent with very thin tips and less numerous or crowded than is characteristic for this genus. When viewed from the front of back they may appear as straight spines, but when turned on their side, show the typical curved hook structure (Fig. 4b).

Internally the longitudinal body musculature is undivided. The one pair of retractor muscles, which fuse into a single muscle, has its origins from the body wall about $70-90 \%$ of the distance to the posterior end, well in front of the caudal shield. When contracted, this can give the appearance of a single retractor muscle with two roots. The two tubular nephridia are $35-75 \%$ of the trunk length and are attached by a mesentery to the body wall for $50-65 \%$ of their length. The coiled gut is attached to the posterior end of the trunk by the spindle muscle. The other end of this spindle muscle attaches anterior to the anus, just beyond the normal wing muscle. The dorsal anus is only slightly anterior to the nephridiopores. A caecum is present where the short rectum leaves the intestinal coil, but no fixing muscle is visible. The contractile vessel is without villi but some exhibit
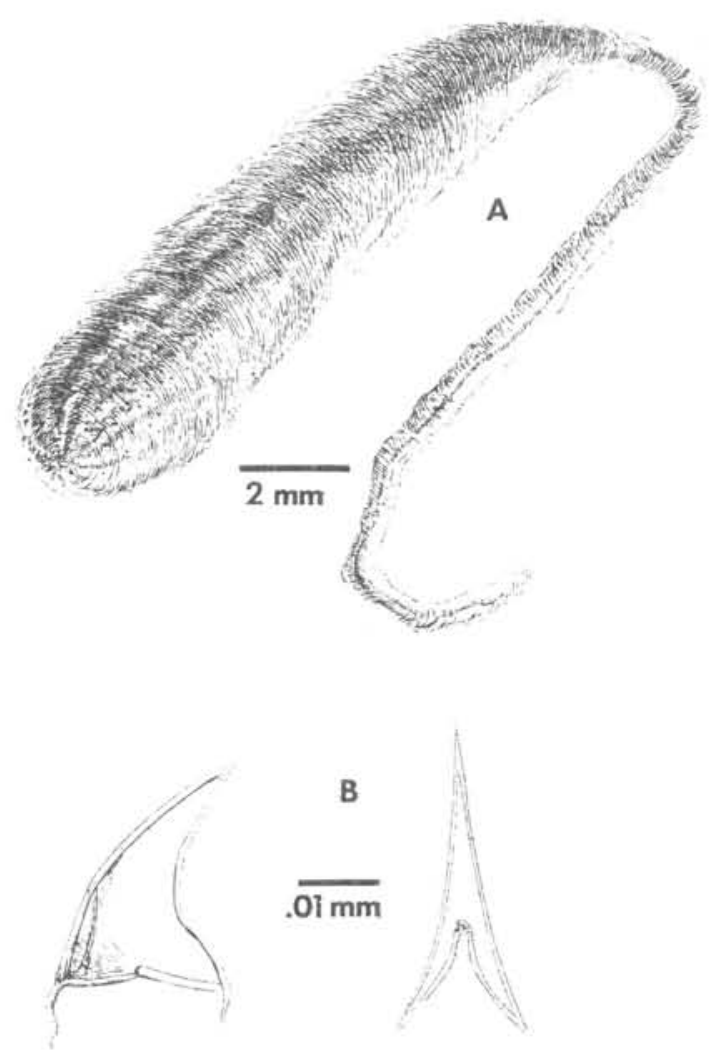

Fig. 4. Aspidosiphon longirhyncus A. external view;

B. hook.

small, bubble-like swellings .

Within the subgenus Aspidosiphonsensu stricto there are two species described with unidentate hooks and retractor muscle origins not on the caudal shield. These are A. ravus and A. cylindricus. The most obvious difference is in the nature of the shields, this new species having a very poorly defined anal shield and a practically nonexistent caudal shield, while the others have the more typical, chitinized, pigmented, defined shields at both ends. An additional differentiation is reflected in the name of this species, i.e., the introvert is proportionately much longer than in either of the other species. With respect to $A$, cylindricus, the key to this genus in Stephen \& Edmonds (1972) erroneously states the nephridia are free for their entire length.

This new species bears many superficial similarities to the newly described Aspidosiphon thomassini (Cutler \& Cutler, 1979b). Both of these have a weakly developed anal shield and no discernible caudal shield. They both have intro- 
verts coming off at a $50-60^{\circ}$ angle from the trunk. The important morphological distinction is that $A$. thomassini is without hooks while A. longirhyncus has single pointed ones. Ecologically A. thomassini is found in littoral, warm water in the Indian 0 cean and $A$. longirhyncus comes from deeper, cooler shelf waters in the Southwestern Atlantic Ocean.

This species occurs at depths between 78 and $194 \mathrm{~m}$ at temperatures between 15 and $19^{\circ} \mathrm{C}$ (one individual at $\left.12.4^{\circ} \mathrm{C}\right)$. The general locality is along the outer shelf off Brazil (Fig. $5)$, The name given this species reflects the unusually long introvert and was suggested by Dr. Galena Murina. Holotype: Station 432 deposited in the American Museum of Natural History, New York; catalogue number AMNH 4022.

Paratypes: Station 432 deposited at Instituto Oceanográfico, Universidade de São Paulo.

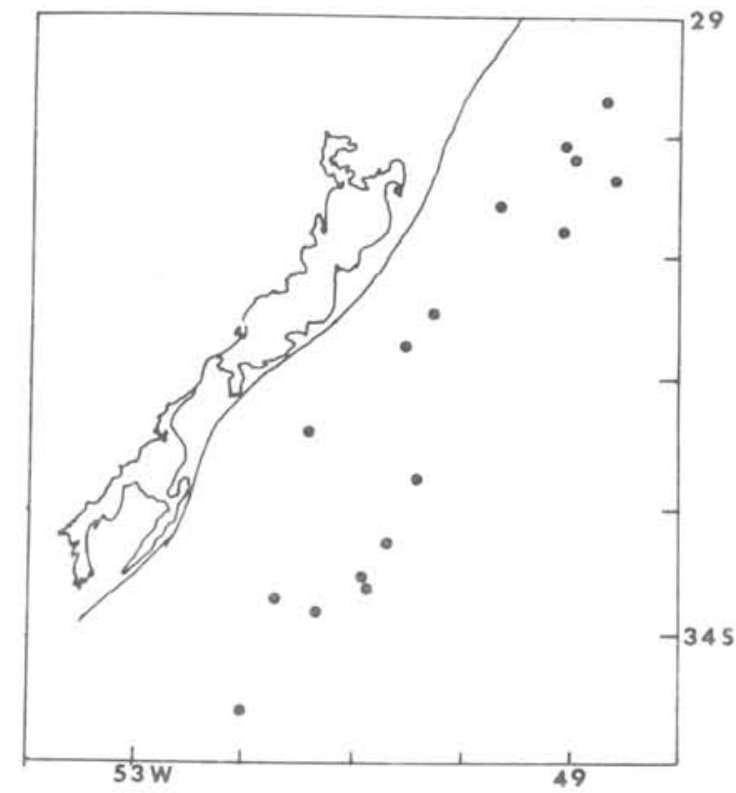

Fig. 5. Distribution of Aspidosiphon longirhyncus.

\section{Discussion}

One notable aspect of this collection is the overwhelming number of individuals (74\%) which belong to a hitherto undescribed species of Aspidosiphon (A. longirhyncus). This is indicative of the paucity of sampling done at these depths and latitudes in the Southwest Atlantic Ocean. Another interesting fact is that at 14 of the 16 stations yielding this species, it was the only sipunculan present (Phascolion hedraeum co-occurred at two stations). The two Aspidosiphon albus were likewise isolated from other sipunculans. Aspidosiphon exhaustus differed in two ways: it was always found (three stations) with other species and these were deeper $(166-1080 \mathrm{~m})$ and further south $\left(34^{\circ} 25^{\prime}-34^{\circ} 35^{\prime} \mathrm{S}\right)$ than all except one of the A. longirhyncus.

The five Golfingia species all occurred at two of the southerly ( $\left.34^{\circ} 25^{\prime} \mathrm{S}\right)$, deep (166 m and $1080 \mathrm{~m}$ ) stations, showing an evident inability to tolerate temperatures greater than $15^{\circ} \mathrm{C}$. A similar deep, cool, southern pattern was shown by Phascolion medusum, while the other member of this genus ( $P$. hedraeum) was found further north in shallower (54$124 \mathrm{~m})$, warmer $\left(15-20^{\circ} \mathrm{C}\right)$ water (Fig. 6).

Ecologically then, there appears to be two fairly distinct groups in this collection. Three species (Aspidosiphon

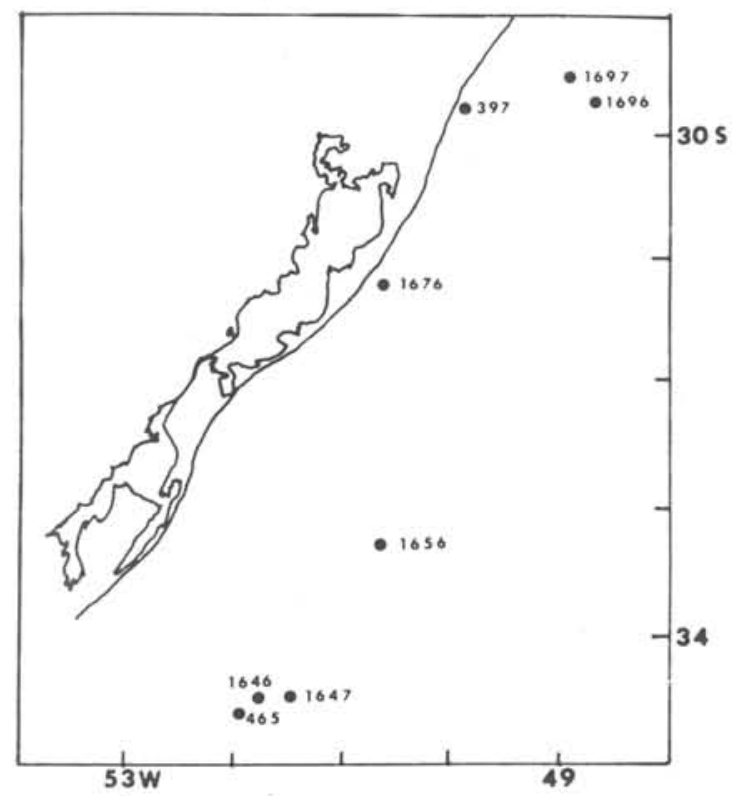

Fig. 6. Distribution of: Golfingia misakiana (1646), G. (Golfingia species (1647), G. eremita: (1647), G. pellucida (1646), G. (Nephasoma) species (1646), Phascolion hedraeum $(1656,1696,1697)$, $P$. medusae $(465,1646)$, Aspidosiphon albus (397, 1676 ), and A. exhaustus (465, $1646,1647)$.

albus, A. longirhyncus, and Phascolion hedraeum) inhabit the subtropical shelf waters. This area marks the southern 
border of the South Brazilian Province (Balech, 1951; Tommasi, 1965). The second group (Aspidosiphon exhaustus, the five Golfingia and Phascolion medusae) seems restricted to cooler (4$15^{\circ} \mathrm{C}$ ), upper slope depths south of $34^{\circ} \mathrm{S}$. Carrera-Rodríguez \& Tommasi (1977) discuss Asteroidea from these same collections and identify four sub-groups.

The thoroughness of the deeper sampling in this area is not impressive but if the above conclusion is meaningful, it points to an intriguing situation. It suggests a mirror image of a zoogeographical barrier shown to exist at $34^{\circ} \mathrm{N}$ latitude on the Continental Slope off North Carolina (Cutler, 1975). More intensive sampling at slope depths is necessary to test this possibility, One additional factor which makes the area between 34 and $35^{\circ} \mathrm{S}$ interesting is characterized by Sta. 1646 which yielded five species. Sta. 1647 at the same latitude $\left(34^{\circ} 25^{\prime} \mathrm{S}\right)$, but deeper, had three species present. This is in contrast to three stations having only two species and the majority (17) yielding only a single species. The concept of an ecotone may be relevant here as border regions between two biotopes are characteristically more diverse than the biotopes themselves. This "edge effect" may also apply between zoogeographical provinces. The high degree of diversity one sees in this region may point in this direction, especially since some inhabitants may be near the upper end of their tolerance and others near the lower end. This situation is similar to that found on the upper slope off North Carolina (Cut1er, 1973; 1975).

The zoogeographical barrier at $34^{\circ} \mathrm{N}$ corresponds to the area where two major currents come together: the Florida Current (Gulf Stream) and the Western Boundary Undercurrent. Here at $34^{\circ} \mathrm{S}$, the southerly flowing Brazil Current meets the northward flowing Falkland Current and the effect of these currents on larval transport is the probable cause of any barriers at slope depths. It seems valid to assume that benthic pelagic larvae would be distributed in a manner similar to finer sediments so that an understanding of sediment transport may help understand larval transport. The Antarctic Bottom Current flows northward under the
Falkland Current in deeper waters (Ewing et. al., 1970) and is shunted offshore by the bottom topography (Rio Grande Rise) near these latitudes. Again it parallels the situation near Cape Hatteras, North Carolina.

\section{Acknowledgements}

This interesting collection of sipunculans was made available to us for study by Dr. Luiz Roberto Tommasi, Universidade de São Paulo, Instituto Oceanográfico, Brazil. The artwork was done by $\mathrm{Mr}$. Henry Iwanicki and the manuscript was completed with the aid of a grant from Utica College.

\section{References}

BALECH, E. 1951. División zoogeogräfica del litoral sudamericano. Revta Bio1. mar., (4):184-195.

CARRERA-RODRIGUEZ, C. J. \& TOMMASI, L. R. 1977. Asteroidea de 1a plataforma continental de Rio Grande do Sul (Brasil), coleccionados durante los viajes del N/Oc. "Prof. W. Besnard" para el Proyecto Rio Grande do Sul. Bolm Inst. oceanogr., S Paulo, 26:51-130.

CUTLER, E. B. 1973. Sipuncula of the Western North Atlantic. Bull. Am. Mus. nat. Hist., 152:105-204.

\section{Zoogeographical} barrier on the continental slope off Cape Lookout, North Carolina. Deep Sea Res., 22:893-901.

\section{A reconsider-} ation of the sipunculan taxa Fisherana Stephen, Mitosiphon Fisher, and Apionsoma Sluiter. Zool. J. Linn. Soc., 65(4): 367-384.

$$
\text { \& CUTLER, N. J. }
$$

Sipuncula. Résultats Scientifiques des Campagnes de 1a Calypso. Annls Inst. océanogr., Monaco, n. s., 55 (fasci. supp1.):103-109.

$1979 b$.

Madagascar and Indian Ocean Sipuncula. Bu11. Mus. Natn. Hist. nat., Paris, $4^{e}$ ser., Sec A, no 4:

EWING, M.; EITTREIM, S. L.; EWING, J.I. \& Le PICHON, X. 1971. Sediment 
transport and distribution in the Argentine Basin. 3. Nepheloid layer and processes of sedimentation. Physics Chem. Earth, 8:49-77.

IKEDA, I. 1904. The Gephyrea of Japan. J. Coll. Sci. imp. Univ, Tokyo, 20(4): $1-87$.

KEFERSTEIN, W. 1865. Beitrage zur anatomischen und systematischen Kenntnis der Sipunculiden. Z. wiss . Zool., 15:404-445.

MURINA, V. V. 1967. Report of the sipunculid worm from the sub-littoral zone of Cuba and Mexican Gulf. Zool. Zh., 46:1329-1339.

SARS, M. 1851. Beretning om en i Sommernen 1849 foretagen zoologisk Reise $i$ Lofoten og Finmarken. Nyt Mag. Naturvid., 6:121-211.
SELENKA, E.; de MAN, J. G. \& BULOW, C. 1883. Die Sipunculiden, eine systematische Monographie. Reisen im Archipel. d. Phillippinen, von Dr. C. Semper. Leipzig, pt. 2 4(1):1133.

SLUITER, G. P. 1912. Gephyriens (Sipunculides et Echiurides) provenant des campagnes de 1a Princesse Alice. 1898-1910. Résult. Camp. scient. Prince Albert I, 36:1-36.

STEPHEN, A. C. \& EDMONDS, S. J. 1972. The phyla Sipuncula and Echiura. London, British Museum (Nat. Hist.), : $1-528$.

TOMMASI, L. R. 1965. Faunistic provinces of the western South Atlantic 1ittoral region. Anais Acad. bras. Ciênc., 37(sup1.): 261-262.

(Received in 09/November/1978) 